\title{
Vocalizations and comments on the relationships of Hypsiboas ericae (Amphibia, Hylidae)
}

\author{
Paulo C. A. Garcia ${ }^{1} \&$ Célio F. B. Haddad ${ }^{2}$
}

\begin{abstract}
1. Museu de Zoologia, Universidade de São Paulo, Av. Nazaré, 481, Ipiranga, 04263-000 São Paulo, SP, Brasil. (pcagarcia@gmail.com) 2. Departamento de Zoologia, Instituto de Biociências, Universidade Estadual Paulista, Caixa Postal 199, 13506-900 Rio Claro, SP, Brasil. (haddad@rc.unesp.br)
\end{abstract}

\begin{abstract}
The vocalizations of Hypsiboas ericae (Caramaschi \& Cruz, 2000) are described and new information on the external morphology and osteology of the species are presented. H. ericae presents a bony spine in the prepolex and the individuals can present green or brown dorsal color, as other species of the Hypsiboas pulchellus (Duméril \& Bibron, 1841) species group. The vocalizations of H. ericae are similar to the vocalizations of Hypsiboas bischoffi (Boulenger, 1887), Hypsiboas guentheri (Boulenger, 1886), and other species in the $H$. polytaenius (Cope, 1870 "1869") clade of the $H$. pulchellus species group, but some osteological aspects are different to those found in the majority of the species of this group.
\end{abstract}

KEYWORDS. Hypsiboas ericae, vocalizations, osteology, Hypsiboas pulchellus group.

RESUMO. Vocalização e comentários sobre as relacões de parentesco de Hypsiboas ericae (Amphibia; Hylidae). As vocalizações de Hypsiboas ericae (Caramaschi \& Cruz, 2000) são descritas e novas informações sobre a morfologia externa e a osteologia da espécie são apresentadas. H. ericae apresenta prepólex terminando em um espinho ósseo e os indivíduos podem ter o colorido dorsal marrom ou verde, como outras espécies do grupo de Hypsiboas pulchellus (Duméril \& Bibron, 1841). As vocalizações de H. ericae são similares às de Hypsiboas bischoffi (Boulenger, 1887), Hypsiboas guentheri (Boulenger, 1886) e às de outras espécies do clado de H. polytaenius (Cope, 1870 "1869") do grupo de H. pulchellus, mas alguns aspectos de sua osteologia são muito diferentes dos encontrados na maioria das espécies do grupo de $H$. pulchellus.

PALAVRAS-CHAVE. Hypsiboas ericae, vocalização, osteologia, grupo Hypsiboas pulchellus.

Hypsiboas ericae (Caramaschi \& Cruz, 2000) was described based on specimens obtained at Chapada dos Veadeiros, Alto Paraíso de Goiás, Goiás, Brazil (CARAmASCHI \& CRUZ, 2000). In the original description, the species was included in the group of Hyla pulchella Duméril \& Bibron, 1841 (now Hypsiboas pulchellus group sensu Faivovich et al., 2005) and related to Hyla marginata Boulenger, 1887, and Hyla semiguttata A. Lutz, 1925 (now Hypsiboas marginatus (Boulenger, 1887) and $H$. semiguttatus (A. Lutz, 1925)). During field studies realized at the type-locality of the species, we did new observations about $H$. ericae, including the vocalization recordings of some specimens. Some information about the diagnosis of the species were also verified by the study of part of the skeleton of some individuals. In this work, we describe the vocalization of $H$. ericae and comment on the species relationships according to the new informations obtained.

In a recent work, FAIVOVICH et al. (2005) transferred the Hyla pulchella species group to genus Hypsiboas and included the species of the Hyla polytaenia group as a clade in the $H$. pulchellus species group.

\section{MATERIAL AND METHODS}

For morphological and osteological studies some specimens from the following collections were examined: MNRJ, Museu Nacional, Rio de Janeiro, RJ, Brazil; MZUSP, Museu de Zoologia, Universidade de São Paulo, São Paulo, SP, Brazil; CFBH, Coleção Célio F. B. Haddad, deposited in the Departamento de Zoologia, Universidade Estadual Paulista, Rio Claro, SP, Brazil.

The osteological characters were analyzed in cleared and stained specimens using the technique of TAYLOR \& VAN DyKe (1985). Vocalizations of H. ericae, obtained from Rio dos Couros, Alto Paraíso de Goiás, central Brazil, in January 2001, were recorded using a Nagra E tape recorder and Sennheiser microphone ME66, and analyzed using the software Canary 1.2.4 in Power Macintosh computer. The sounds were digitalized in 22.1 $\mathrm{kHz}$ and the spectrograms and waveforms were produced using frame length and fast Fourier transform (FFT) of 256 points, frame overlap of $50 \%$ and window function Hamming.

Material examined. BRASIL, Goiás: Alto Paraíso de Goiás, Chapada dos Veadeiros, \&, 11ð MZUSP 93850-93861 (93850 female), collected in 06-10 January 1974 by W.C.A. Bokermann; MNRJ 15875-15896 (15896 female), paratypes, collected in 22-25 April 1992 by U. Caramaschi; CFBH 3599-3604 (males) collected in 17 January 2001 by P.C.A. Garcia; (CFBH 67626765) 16 December 2003 by C. F. B. Haddad, R. P. Bastos, L. F. Toledo, L. Guimarães, and L. Lima. CFBH 3603 and 3604 cleared and stained.

\section{RESULTS}

Vocalization. Two males were recorded on 17 January 2001. Three distinct calls were observed in $H$. ericae (Fig. 1). The first of them, here denominated call "A" (Fig. 2), was the most frequent, being emitted 43 times in nine minutes of recording ( $\bar{x}=4.8$ calls $/ \mathrm{min})$. It is composed by an isolated note ("a" note), with pulsed 
structure of $8-20$ pulses/note $(=14.5 \pm 2.74)$, with duration of 33.6-92 ms ( $=67.5 \pm 13)$ and frequency between $2.03-3.6 \mathrm{kHz}(=2.7 \pm 1)$. The second call, denominated "B" call (Fig. 3), was the less frequent, being emitted 16 times in nine minutes ( $=1.8 \mathrm{call} / \mathrm{min}$ ), with duration of $229.8-317.9 \mathrm{~ms}(=283.6 \pm 20.3)$. This call is composed by two notes of pulsed structure: the first note is similar to "a" note of " $\mathrm{A}$ " call, with mean duration slightly larger, between 59.4 and $89.5 \mathrm{~ms}$ ( =75.5 \pm 9.1 ), and frequency and number of pulses similar (Tab. 1) to those of note "a"; the second note, denominated "b" note, had smaller duration, between 40.9 e $62.5 \mathrm{~ms}(=49.6$ \pm 7.3 ), frequency between $2.09-3.54 \mathrm{kHz}(=2.8 \pm 0.6)$, and $7-10$ pulses/note ( $=8.2 \pm 1.1)$. The third call, "C" call (Fig. 4), was emitted 29 times in nine minutes ( $=3.2$ call/ min), had a simple note, denominated "c" note, with
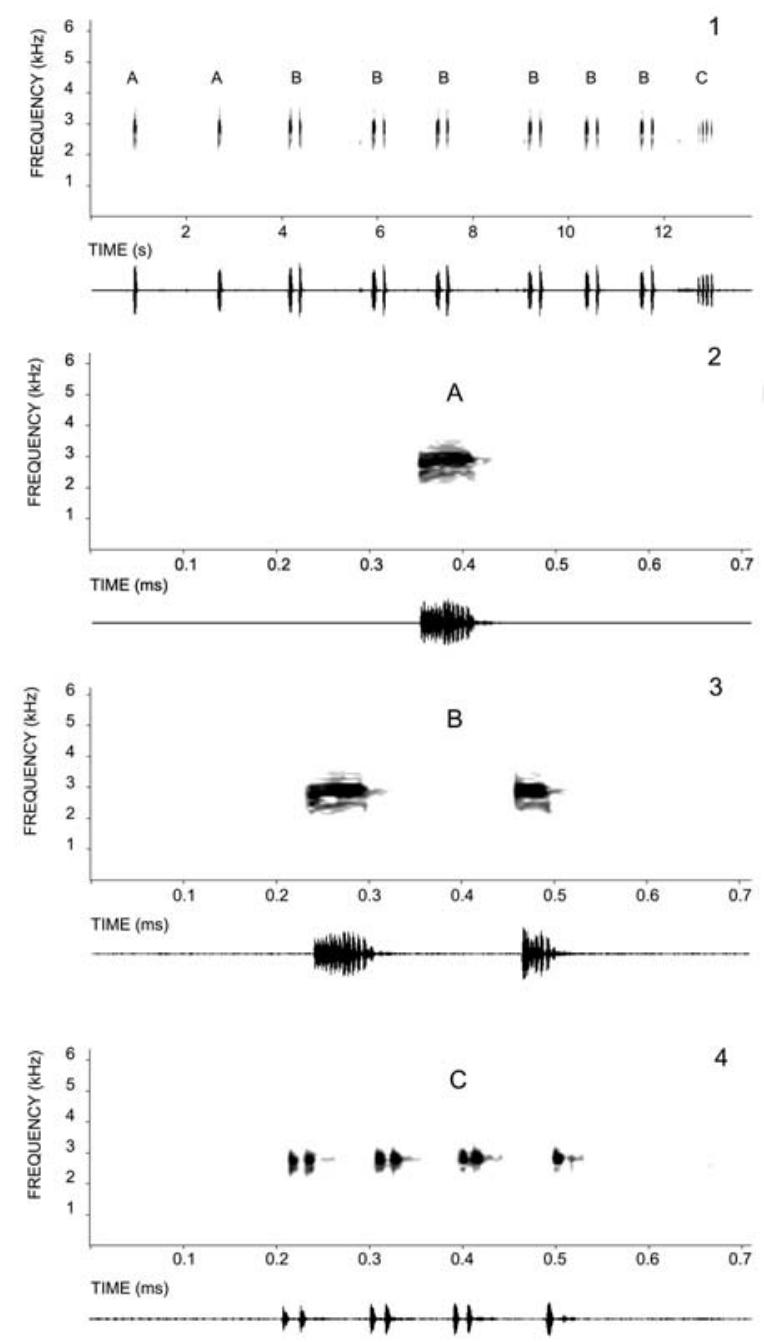

Figs. 1-4. Spectrogram (upper) and waveform (lower). (1) A continuous sequence of nine calls emitted by Hypsiboas ericae (Caramaschi \& Cruz, 2000), showing A (2 calls), B (6 calls), and C calls. Recorded on 17 January 2001, 23:06 h; air temperature $20^{\circ}$ C. Voucher specimen CFBH 3600. (2) The first call (A) of spectrogram of fig. 1, showing a simple pulsed note. (3) Third call (B call) of spectrogram of fig. 1, showing a call with two pulsed notes, the first with identical structure than note of A call. (4) Last call (C) of spectrogram of fig. 1; showing a pulsed note (trill), with seven pulses better defined. pulsed structure, from $2-11$ pulses/note $(=4.8 \pm 2.1)$, duration between 103.6-560.3ms $(239.3 \pm 138.4)$, and frequency between 2.12-3.54 ( $=2.8 \pm 0.4$ ). The "c" note is a trill, composed by pulses better defined than the previous notes, with duration of $6.1-49.9 \mathrm{~ms}(=13.8 \pm$ 7.92). The three calls are emitted independently from each other. The "C" call can be preceded by another "C" call, by an "A" call or a "B" call, occurring the same with the other calls. The calls " $\mathrm{B}$ " and " $\mathrm{C}$ " are more frequent when there are more individuals vocalizing. The function of each call is not clear, but judging for the constancy, the "A" call might correspond to the advertisement call and the " $C$ " call to the territorial call; the function of the " $\mathrm{B}$ " call is unknown.

Color in life of the examined specimens. Dorsal color brown or green, with or without dark blotches. When there are blotches, these are rounded, large, and distributed irregularly along the dorsal surfaces of body and limbs. Dark brown dorsal blotches in brown specimens and dark green in green ones. A white dorsolateral stripe delimited inferiorly by a brown line, both from the superior eyelid to the inguinal region. Flanks dark brown (even in green specimens) with many small blotches, framed by a dark brown line. Some of the blotches fused, making larger and extended blotches. A whitish stripe on the upper lip, from the tip of snout to the arm insertion. Posterior surface of thigh not pigmented. Supra cloacal region with white and a dark brown stripe. Venter whitish, slightly darker in the chest and throat. Iris gold or tan, slightly lighter on the upper area.

Natural history. Specimens of H. ericae were found vocalizing on bushes and trees, always close to water, between 0.1 to $1 \mathrm{~m}$ above the ground along limpid water streams inside or near gallery forest. The vocalization begins in the sunset. Males were found vocalizing in December and January. Males showed scars on the back (Fig. 5), probably a consequence of fights between males, with the use of prepollical spines. Females, clutches, and tadpoles were not found.

Comparison of osteology of Hypsiboas ericae and related species. Some specimens have green bones and others white. Some characteristics differentiate H. ericae

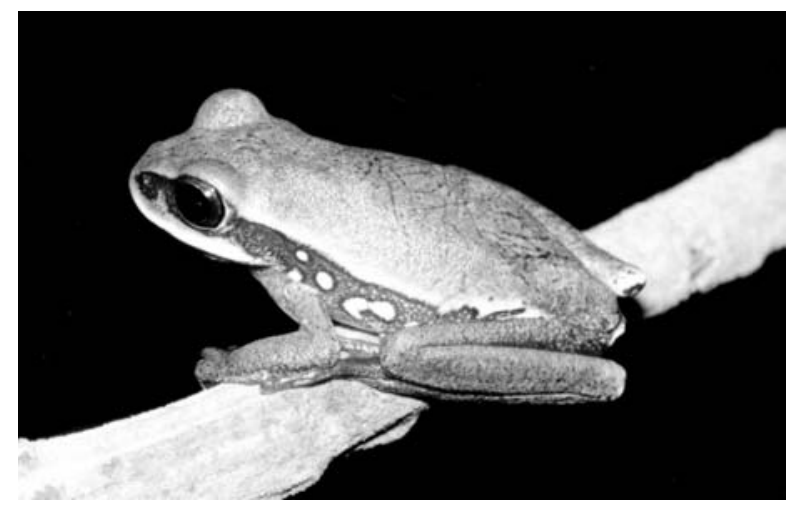

Fig. 5. Adult male of Hypsiboas ericae (Caramaschi \& Cruz, 2000) (CFBH 3600). Note the scars on the back. 
from some of the species included in the group of $H$. pulchellus (Duméril \& Bibron, 1841), mainly from $H$. marginatus (Boulenger, 1887) and $H$. semiguttatus (A. Lutz, 1925). The main differences are: (1) distal tip of cultriform process of parasphenoid rounded in $H$. ericae and pointed in $H$. marginatus, $H$. semiguttatus, $H$. prasinus (Burmeister, 1856), and H. pulchellus (Fig. 6 and 7); (2) humerus slender, with a rudimentary crista ventralis and medialis in H. ericae (Fig. 8), H. pulchellus, and $H$. prasinus (Fig. 9), and robust, with a crista ventralis and medialis largely developed in $H$. marginatus (Fig. 10) and H. semiguttatus (Fig. 11); (3) prepollex present,
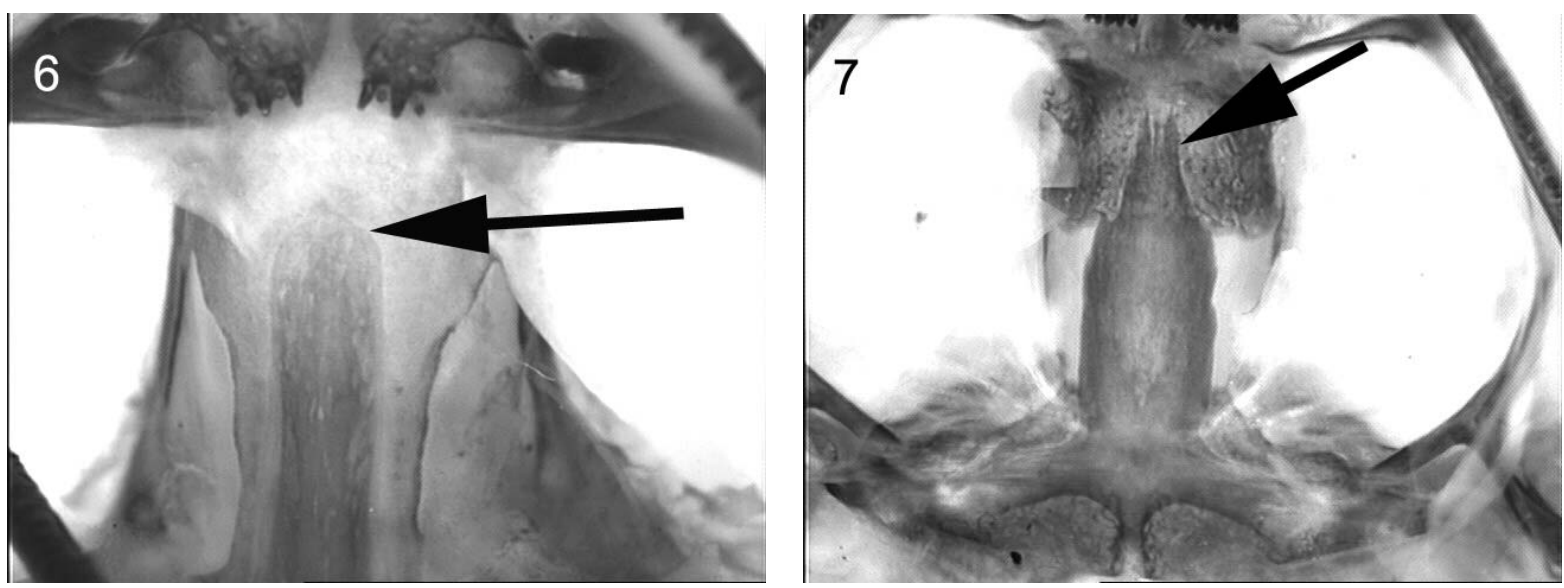

Figs. 6-7. Distal part of cultriform process (arrow) of parasphenoid. 6, Rounded in Hypsiboas ericae (Caramaschi \& Cruz, 2000) (CFBH 3604). 7, Acute and cut in Hypsiboas marginatus (Boulenger, 1887) (CFBH 3613).
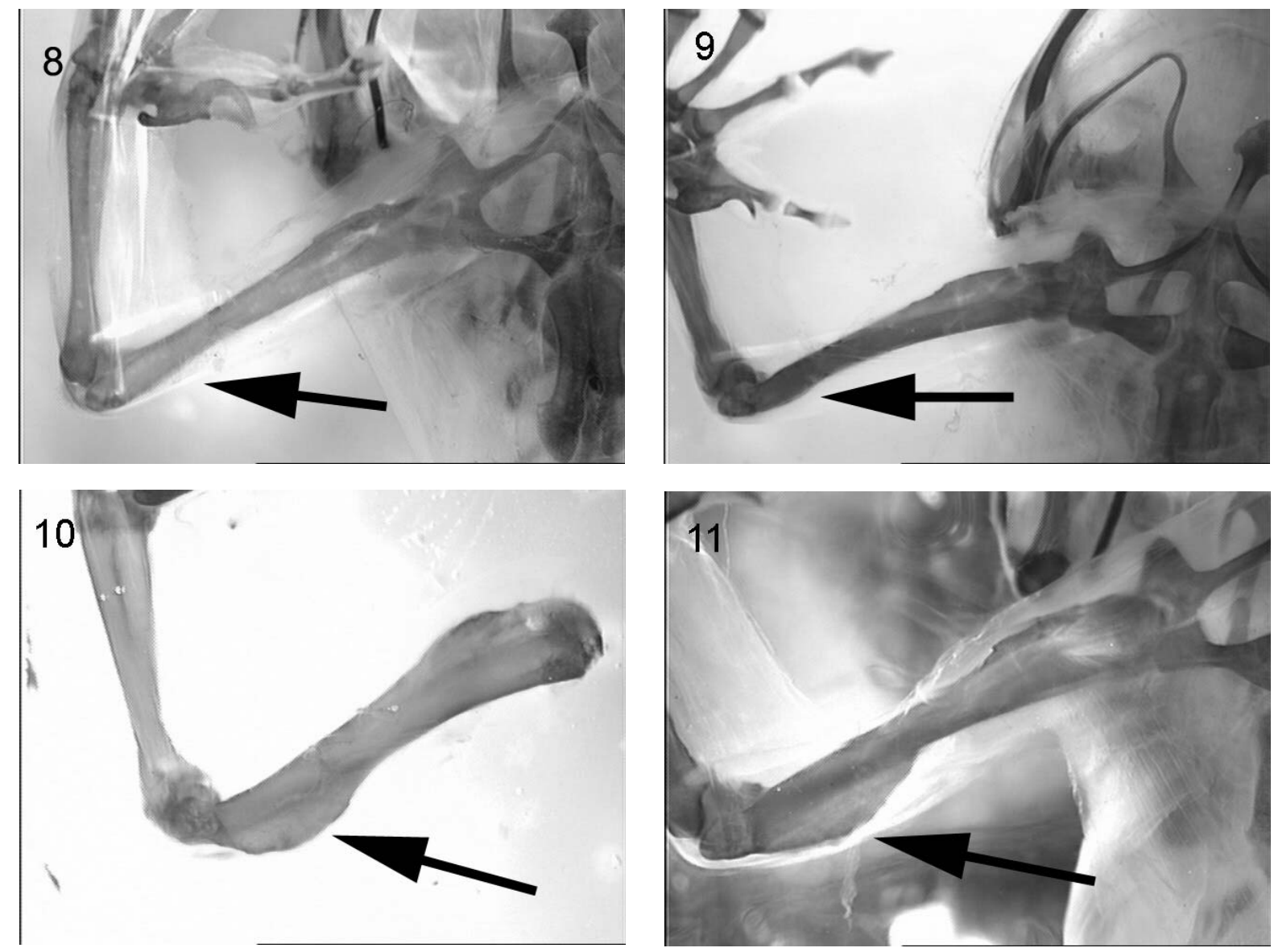

Figs. 8-11. Humerus. 8, Hypsiboas ericae (Caramaschi \& Cruz, 2000) (CFBH 3604). See the slender bone without development of crista ventralis. 9, Hypsiboas prasinus (Burmeister, 1856) (CFBH 1318). Note the slender bone without development of crista ventralis. 10, Hypsiboas marginatus (Boulenger, 1887) (CFBH 3613). Note the strength bone and the development of crista lateralis (CL) and crista ventralis (CV). 11, Hypsiboas semiguttatus (A. Lutz, 1925) (CFBH 3581), showing the development of crista lateralis (CL) and crista ventralis $(\mathrm{CV})$. 
ending in a very robust and curved distal spine (almost $90^{\circ}$ ) (Fig. 12), while in H. marginatus and H. semiguttatus the spine is robust, but less curved (Fig. 13); in $H$. prasinus and $H$. pulchellus the spine is very curved, but less robust (Fig. 14 and 15); (4) the crista ventralis from the prepollical basis is very pronounced anteriorly in $H$. ericae, forming a second spine (Fig. 12), while the crista ventralis is developed in $H$. semiguttatus and $H$. marginatus, but does not form a spine anteriorly (Fig. 13), and is almost indistinct in $H$. prasinus and $H$. pulchellus (Fig. 14 and 15); (5) the sacral diapophysis is long and distally less broaded in H. ericae (Fig. 16), short and distally broad in $H$. semiguttatus, $H$. marginatus, $H$. pulchellus, and H. prasinus (Fig. 17).

Table 1. Physical parameters of vocalizations of Hypsiboas ericae (Caramaschi \& Cruz, 2000) (two analyzed specimens). Upper line, range; lower line, mean (standard deviation). Recordings PCAG 20/1 and 20/3.

\begin{tabular}{|c|c|c|c|c|c|c|c|c|}
\hline $\begin{array}{l}\text { Call } \\
\text { types }\end{array}$ & $\begin{array}{l}\text { Note } \\
\text { types }\end{array}$ & $\begin{array}{l}\mathrm{N}^{\circ} \text { Sampled } \\
\text { notes }\end{array}$ & $\begin{array}{c}\text { Notes/ } \\
\text { call }\end{array}$ & $\begin{array}{l}\text { Note duration } \\
(\mathrm{ms})\end{array}$ & $\begin{array}{l}\text { Range Frequency } \\
(\mathrm{kHz})\end{array}$ & $\begin{array}{l}\text { Pulses/ } \\
\text { note }\end{array}$ & $\begin{array}{l}\text { Pulses duration } \\
\text { (ms) }\end{array}$ & $\begin{array}{l}\text { Call duration } \\
(\mathrm{ms})\end{array}$ \\
\hline \multirow[t]{2}{*}{ A } & $\mathrm{a}$ & 43 & 1 & $33.6-92.0$ & $2.03-3.60$ & $8-20$ & & $33.6-92.0$ \\
\hline & & & & $67.5(13.0)$ & $2.7(1.04)$ & $14.5(2.74)$ & & $67.5(13.0)$ \\
\hline \multirow[t]{4}{*}{ B } & $\mathrm{a}$ & 16 & 1 & 59.4-89.5 & $2.01-3.60$ & $12-18$ & & $229.8-317.9$ \\
\hline & & & & $75.5(9.1)$ & $2.7(0.6)$ & $14.3(1.7)$ & & $283.6(20.3)$ \\
\hline & b & 16 & 1 & $40.9-62.5$ & $2.09-3.50$ & $7-10$ & & \\
\hline & & & & $49.6(7.3)$ & $2.7(0.6)$ & $8.2(1.1)$ & & \\
\hline \multirow[t]{2}{*}{$\mathrm{C}$} & $\mathrm{c}$ & 29 & 1 & $103.6-560.3$ & $2.29-3.54$ & $2-11$ & $6.1-49.9$ & $103.6-560.3$ \\
\hline & & & & $239.5(138.4)$ & $2.8(0.4)$ & $4.8(2.1)$ & $13.8(7.92)$ & $239.5(138.4)$ \\
\hline
\end{tabular}
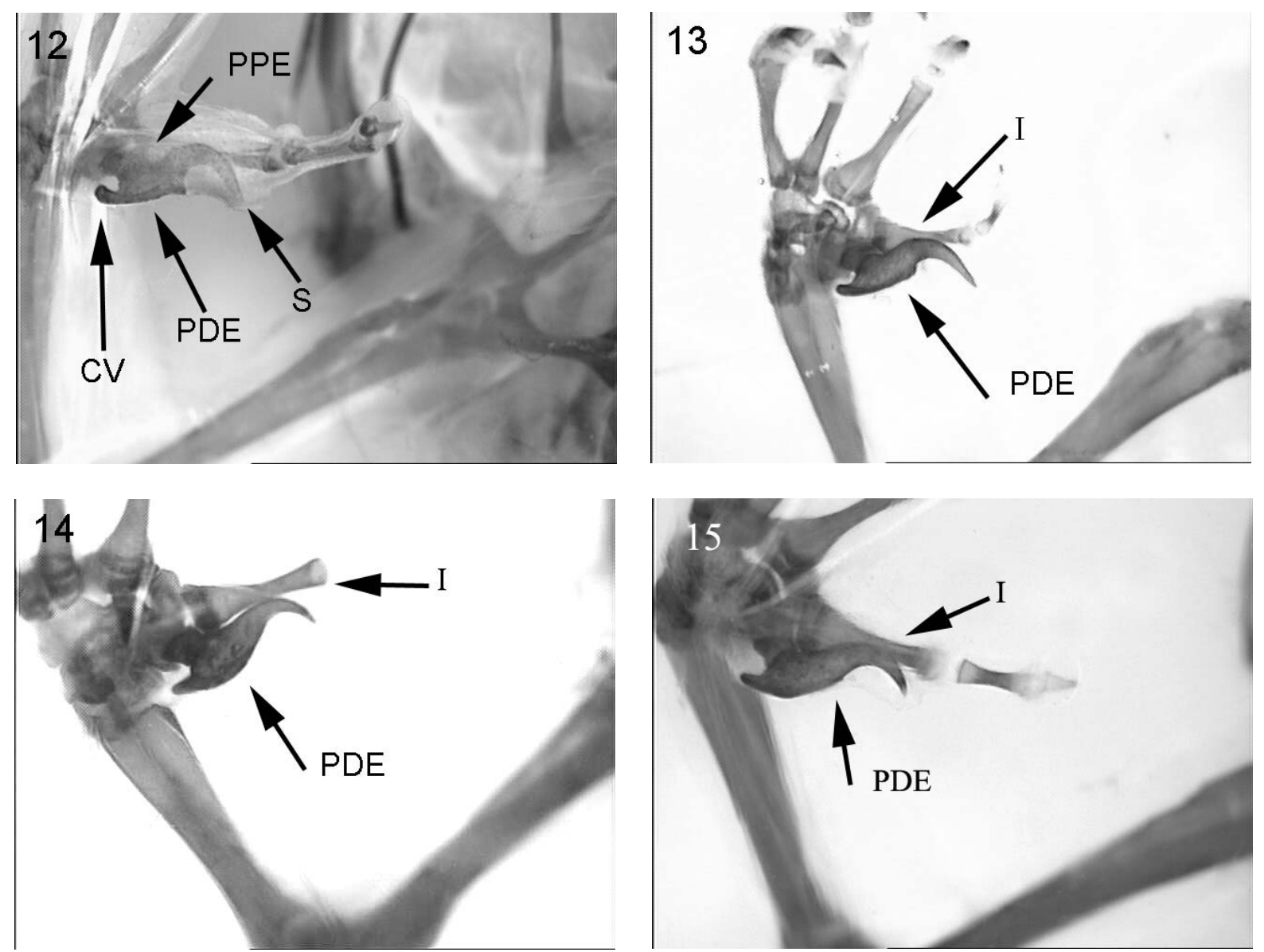

Figs. 12-15. Prepollex. 12, Hypsiboas ericae (Caramaschi \& Cruz, 2000) (CFBH 3604). See the spine curve and the anterior development of crista ventralis (arrow), making a second spine. 13, Hypsiboas marginatus (Boulenger, 1887) (CFBH 3613). 14, Hypsiboas pulchellus (Duméril \& Bibron, 1841) (CFBH 3577). Note the broaded base (arrow) and the small development of spine in relation to the first phalange of digit I (I). 15, Hypsiboas prasinus (Burmeister, 1856) (CFBH 3618). Note poor development of spine in relation to the first phalange of digit I. (PPE, prepollex proximal element; PDE, prepollex distal element; S, spine; CV, crista ventralis; I, first phalange of digit I). 

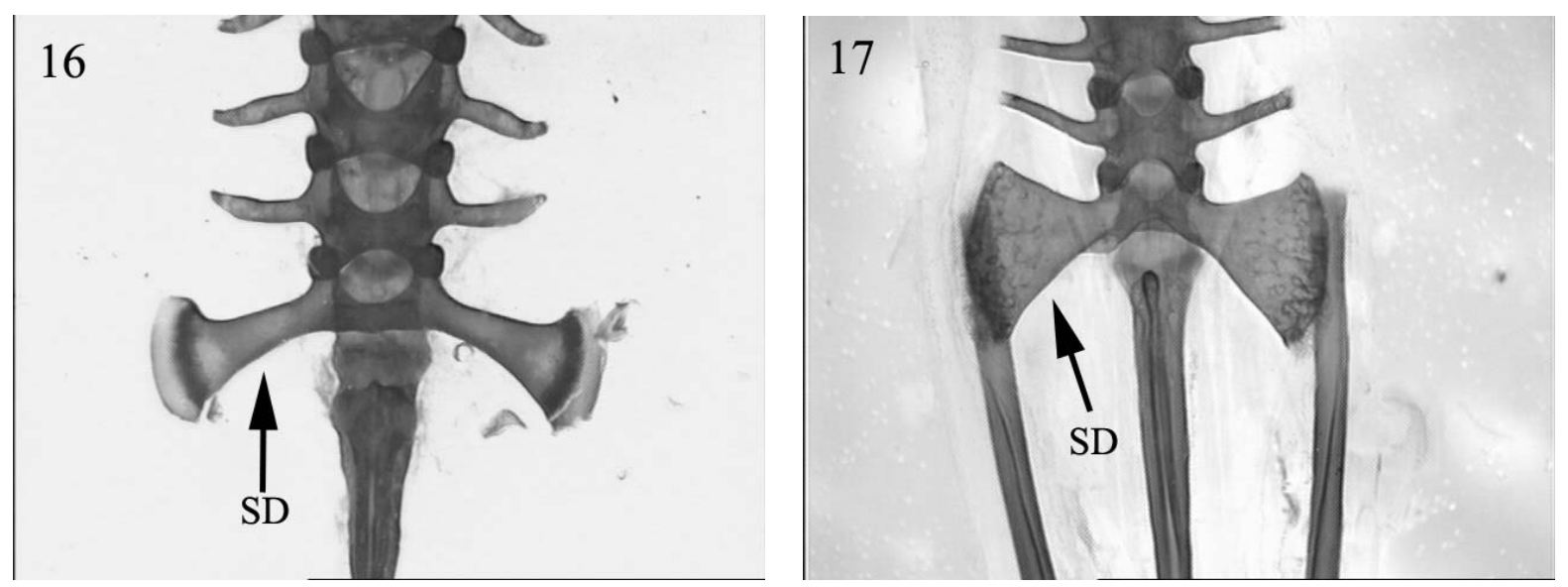

Figs. 16-17. Sacral diapophysis (SD). 16, Small broaded SD of Hypsiboas ericae (Caramaschi \& Cruz, 2000) (CFBH 3604). 17, Broad SD of Hypsiboas marginatus (Boulenger, 1887) (CFBH 3412).

\section{DISCUSSION}

CARAmaschi \& CRUZ (2000) included Hypsiboas ericae in the group of Hypsiboas pulchellus, considering it more closely related with $H$. marginatus and $H$. semiguttatus, due to the robust aspect of the body and the presence of a longitudinal white stripe situated dorsolaterally. The pointed differences between $H$. ericae and those species were: smaller size, absence of spine on the prepollex, and white bones. However, males of $H$. ericae have prepollical spine and, apparently, use it in fights in the same way as reported for other species in the group of $H$. pulchellus (GARCIA et al., 2001, 2003) and in the clade Hypsiboas polytaenius (Cope, 1870 "1869") (MENin et al., 2004), judging by the scars on the back of some males. The presence of green bones in $H$. semiguttatus was mentioned by LuTZ (1973); LANGONE (1997) quoted this characteristic to H. marginatus. Even though this character is evident in live specimens, in preserved ones it disappears. Moreover, in the same population of H. joaquini (B. Lutz, 1968) (another species of the $H$. pulchellus species group), Garcia et al. (2003) noticed the presence of some specimens with green or white bones, showing that this character can be polymorphic among specimens of the same population.

Related to the external morphology, the characteristics that indicate a close relationship between $H$. ericae and the species of $H$. pulchellus group are: (1) white stripe in the upper lip; (2) dorsolateral white stripe; (3) brown or green colored body; (4) pronounced prepollex ending in curved spine; (5) small white rounded blotches on the flanks (absent in $H$. marginatus and species of $H$. polytaenius clade); (6) absence of blotches in the concealed areas of thigh; and (7) presence of green or white bones.

The vocalization of $H$. ericae differs from all other species of the $H$. pulchellus group with known vocalization. However, some elements might be similar. The "A" and "B" calls of $H$. ericae are structurally similar to the calls of $H$. pulchellus, with the difference that in $H$. pulchellus the notes have lower duration and are not pulsed (see GARCIA et al. 2003). The "C" call is similar to a part of the call of $H$. caingua (Carrizo, 1990) (pers. obs.) and of $H$. prasinus (see BARRIO, 1965) (both species included in the group of $H$. pulchellus sensu DuELLMAN et al., 1997). However, the call of $H$. ericae shows more similarities with the advertisement calls of species in the clade of $H$. polytaenius (Cope, 1870), as H. leptolineatus (Braun \& Braun, 1977) (personal observation), Hypsiboas sp. (aff. polytaenius) (Heyer et al., 1990, as H. polytaenius), and H. goianus (B. Lutz, 1968) (GUIMARÃEs et al., 2001; Menin et al., 2004). Also shows similarities with the vocalizations of other species that were not included in formal groups, but eventually appear quoted in the groups of $H$. pulchellus or of $H$. polytaenius, as $H$. guentheri (Boulenger, 1886) (pers. obs.) and H. bischoffi (Boulenger, 1887) (see Heyer et al., 1990, as $H$. multilineatus B. Lutz, 1939). These species have the call with one or two pulsed notes and a trill emitted in the sequence.

Although the general skeleton of $H$. ericae is relatively similar to some species of the $H$. pulchellus group (which is expected in Hylinae, since the skeletons of the majority of species are very similar; see Duellman, 2001), many differences were observed among $H$. ericae, $H$. marginatus, $H$. prasinus, $H$. pulchellus, and $H$. semiguttatus.

A recent phylogenetic study based on mitochondrial DNA showed that the group of Hyla pulchella was paraphiletic related to the group of Hyla polytaenia and also to the species Hyla bischoffi and Hyla guentheri Boulenger, 1886 (FAIVovich et al., 2004). In this work, Hyla ericae appears as the sister taxon of the group, which is represented by two clades, one of which involving two species of Hyla polytaenia group + $H y l a$ semiguttata and $H$. joaquini; and other involving the other specimens analyzed in the group of $H$. pulchella (lato sensu). More recently, Faivovich et al. (2005) formalized the proposal, transferring the Hyla pulchella species group to the revalidated genus Hypsiboas, where Hypsiboas pulchellus group, including all species of the group of Hyla pulchella, plus Hyla bischoffi, Hyla guentheri, and all species of the Hyla polytaenia species group (sensu CRUZ \& CARAMASCHI, 1998) as a clade of the Hypsiboas pulchellus group. These results corroborate the observations made here. By one side, $H$. ericae 
presents morphological and biological characteristics shared with specimens considered in the group of $H$. pulchellus (GARCIA et al., 2001, 2003); on the other side, presents vocalization with similar characteristics to the vocalizations of species included in the group of $H$. polytaenius (sensu CRUZ \& CARAMASCHI, 1998). However, H. ericae presents exclusive osteological characteristics, which is in agreement to its position as sister group of all the other species of the Hypsiboas pulchellus species group.

Acknowledgements. M. Di Bernardo (in memoriam) (MCP), U. Caramaschi and J. P. Pombal Jr. (MNRJ), M. T. Rodrigues (MZUSP), M. L. M. Alves and M. L. Araújo (MCN), loaned and/or permitted access to material under their care. R. P. Bastos, L. F. Toledo, L. P. Lima and L. D. Guimarães for field assistance. P. C. A. Garcia acknowledges IBAMA for the license (02001.000635/01-11) and financial support from FAPESP (proc. n. 98/06087-9), and C. F. B. Haddad acknowledges IBAMA for the license (02001.002792/98-03), FAPESP (proc. n. 01/13341-3), and $\mathrm{CNPq}$ (Bolsa de Produtividade em Pesquisa).

\section{REFERENCES}

Barrio, A. 1965. Las subespecies de Hyla pulchella Duméril y Bibron (Anura, Hylidae). Physis 25(69):115-128

Cruz, C. A. G. \& Caramaschi, U. 1998. Definição, composição e distribuição geográfica do grupo de Hyla polytaenia Cope, 1870 (Amphibia, Anura, Hylidae). Boletim do Museu Nacional (N. S.) Zoologia 392:1-19.

Caramaschi, U. \& Cruz, C. A. G. 2000. Duas espécies novas de Hyla Laurenti, 1768 do Estado de Goiás, Brasil (Amphibia, Anura, Hylidae). Boletim do Museu Nacional (N. S.) Zoologia 422:1-12.

Duellman, W. E. 2001. The Hylid frogs of Middle America Contributions to Herpetology 18. Society for the Study of Amphibians and Reptiles/Natural History Museum of the University of Kansas. i-xvi + 1158pp. 92pls.
Duellman, W. E.; De La Riva, I. \& Wild, E. R. 1997. Frogs of the Hyla armata and Hyla pulchella groups in the Andes of South America, with definitions and analyses of phylogenetic relationships of Andean groups of Hyla. Scientific Papers of the Natural History Museum of the University of Kansas 3:1-41.

Faivovich, J.; Garcia, P. C. A.; Ananias, F.; Lanari, L.; Basso, N. G. \& WheEler, W. C. 2004. A molecular perspective on the phylogeny of the Hyla pulchella species group (Anura, Hylidae). Molecular Phylogenetics and Evolution 32:938-950.

Faivovich, J.; Haddad, C. F. B.; Garcia, P. C. A.; Frost, D. R., Campbell, J. A. \& Wheeler, W. C. 2005. Systematic review of the frog family Hylidae, with special reference to Hylinae: phylogenetic analysis and taxonomic revision. Bulletin of the American Museum of Natural History 294:1-240.

Garcia, P. C. A.; Vinciprova, G. \& Haddad, C. F. B. 2001. Vocalização, girino, distribuição geográfica e novos comentários sobre Hyla marginata Boulenger, 1887 (Anura, Hylidae, Hylinae). Boletim do Museu Nacional (N. S.) Zoologia 460:1-19.

2003. The taxonomic status of Hyla pulchella joaquini B. Lutz, 1968 (Anura, Hylidae, Hylinae). Herpetologica 59:350-364.

Guimarães, L. D.; Lima, L. P.; Juliano, R. F.; \& Bastos, R. P. 2001. Vocalizações de espécies de anuros (Amphibia) no Brasil Central. Boletim do Museu Nacional (N. S.) Zoologia 474: $1-14$.

Heyer, W. R.; Rand, A. S.; Cruz, C. A. G.; Peixoto, O. L. \& Nelson, C. E. 1990. Frogs of Boracéia. Arquivos de Zoologia 31:231-410.

LANGone, J. A. 1997. Caraterización de Hyla guentheri Boulenger, 1886 (Amphibia, Anura, Hylidae). Cuadernos de Herpetologia 11:13-20.

Lutz, B. 1973. Brazilian species of Hyla. Austin and London, University of Texas. xix $+265 p$.

Menin, M.; Silva, R. A. \& Giaretta, A. A. 2004. Reproductive biology of Hyla goiana (Anura, Hylidae). Iheringia, Série Zoologia, 94(1):49-52.

TAYlor, W. \& VAN Dyke, G. C. 1985. Revised procedures for staining and clearing small fishes and other vertebrates for bone and cartilage study. Cybium 9:107-119.

Recebido em feveriro de 2006. Aceito em janeiro de 2008. ISSN 0073-4721

Artigo disponível em: www.scielo.br/isz 